\title{
The Role of Citizen Journalism in Jelajah Pagi Program on Gema Surya FM Radio Ponorogo: Case Study on PO942 Facebook Group
}

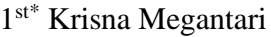 \\ Communication Science Department \\ Universitas Muhammadiyah Ponorogo \\ Ponorogo, Indonesia \\ megantarikrisna@gmail.com
}

\author{
$2^{\text {nd }}$ Andi Prayoga \\ Communication Science Department \\ Universitas Muhammadiyah Ponorogo \\ Ponorogo, Indonesia \\ prayoga.andi24@gmail.com
}

\begin{abstract}
This paper was titled "The Role of citizen journalism in Jelajah Pagi program at Gema Surya FM radio Ponorogo".The researcher intended to know how much the role of citizen as citizen journalism in Jelajah Pagi program through the PO942 Facebook group as well as the extent of citizen knowledge about citizen journalism and journalistic values because it was important to understand it before writing a news. This research utilized qualitative research methods. In this study, the analysis of qualitative data was inductive, namely analyses conducted based on data that had been obtained previously. Furthermore, the data obtained were examined using the theory of $D$. Lasica about the typesof Citizen Journalism in which there were 6 points namely (a) audience Participation (b) Independent News and Information Website (c) Full-Fledged Participatory News Sites (d) Collaborative and Contributory Media Sites (e) Other Kinds of Thin Media (f) Personal Broadcasting Sites. Based on the results of the research, itwas proven that the citizen had a major role of citizen journalism in Jelajah Pagi program on GemaSurya FM radio through PO942 Facebook group because indeed all the original information derived from the citizens and programs could not run without the contributions from the citizens. However, the sense of citizen regarding the important journalistic values in the writing of the news was not yet understood, so the citizens still very much needed more education. After being examined using the theory of $D$. Lasica regarding the media typesof Citizen Journalism, there were some of them which had not been completed, but in some points of the theory, most were achieved and run based on the process of citizen journalism in the Gema Surya FM radio.
\end{abstract}

Keywords-Citizen Journalism, Gema Surya FM, Radio, Facebook

\section{INTRODUCTION}

Citizen Journalism (henceforth-CJ) is a new development in the world of journalists. Although CJ is fairly new in the world of journalists, many media in Indonesia have started to be open to receive information sourced from citizens. There have been many conventional mass media such as radio, television, and others that have special segments to display CJ information. National Television which often broadcast CJ news and even has a special segmentation for CJ is NET TV. NET TV actively promotes CJ and comes to several campuses to conduct training and share tips on writing good and trustworthy news.

Related to the development of journalism, the development of the internet also finally brings out a new generation of journalism called online journalism, also called cyber journalism. Online journalism is the delivery of information using internet media on websites and other possible platforms [1].

In its development, the emergence of CJ was rejected by mainstream media who argued that citizen journalists were not professionals who could report like professional journalists. One example is The New York Times, which questions the accuracy and objectivity of CJ's coverage. Traditional journalists also claimed to be skeptical and considered CJ to not be able to do good reporting.

CJ is closely related to the information society, that is individuals whose work fields produce, process, distribute information, or their daily activities cannot be separated from modern technology. In other words, information affects their daily life [2].

A study by Secur Envoy in the United Kingdom (2012) states that around two-thirds of the 1000 people studied feel fear if they lose or live without a cell phone. The study also mentions the age range of those suffering from nophobia (people who are afraid of living without a cell phone) around $18-24$ years $(77 \%)$, then followed by the respondents aged 25-35 years $(68 \%)$ [3].

CJ continues to grow even though their skills are doubted by professional journalists. In fact, on various occasions, CJ becomes number one who provided information to the public. CJ has one advantage that professional journalists do not, namely the speed and moment of events.

In this paper, the researchers intend to examine the sensitivity and contribution of the people of Ponorogo as citizen journalism and share recordings and information on events that occur around them. The current development of technology seems to provide a new trend of communication styles between people. In contrast to the past, the 
dissemination of information will certainly be very fast since there is a change in communication style in which communication is done through various applications provided by social media platforms.

One of the radio stations in Ponorogo, Gema Surya FM, provides space for Citizen Journalism to share information that they have captured. The information will then be broadcast on a broadcast program containing morning news and information entitled "Jelajah Pagi".It certainly provides a forum for people to voice their aspirations and share information and events around them.Citizens can contribute to $\mathrm{CJ}$ via interactive telephone calls or by writing on the P0942 Facebook group page. Of the two methods, most citizens prefer to share their information through the PO942 group website since it is easier to do because the average people access facebook.

"Jelajah Pagi" on Gema Surya FM is an informative program that reads some actual events around Ponorogo, as well as other locations around Ponorogo. This program starts broadcasting at 6:00 to 11:00 every morning at Gema Surya $F M$. The segmentation of this event is all Ponorogo citizens, including those who are still living in Ponorogo or who are already domiciled in other cities with an age range below 50 years and above 25 years, especially for contributors. This is because if the age is less or more, the information provided is still inaccurate and cannot be justified.In this program, there is a special segment for citizen journalism where information that has been shared through the PO942 Facebook group or interactive telephone with broadcasters in the studio is read. The contributors usually prefer to share their information through the PO942 Facebook group page. In this group, people are free to join and can read and write the actual information that they find. Besides admin, members can also add posts in the group and there is a possibility that the writing will be included in the program.

The focus of the researchers is how much awareness of the people to become citizen journalism, how much the people contribution in the program, and their sensitivity in capturing an event around it

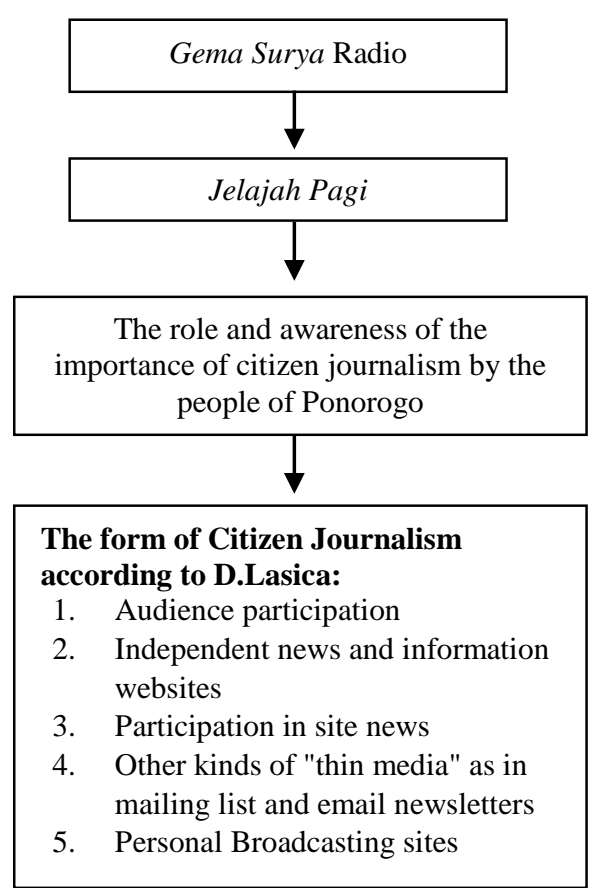

Fig. 1. Theoretical Framework

\section{RESEARCH METHODOLOGY}

PT. Radio Gema Surya, with the name of the broadcast Gema Surya FM, broadcasts with an FM frequency of 94.2 $\mathrm{MHz}$ which is located at Jl. Merbabu No. 67 Nologaten Ponorogo.This research utilizes a qualitative approach.

This research was closely related to citizen journalism in the "Jelajah Pagi" program on Gema Surya FM Radio Ponorogo. Therefore, it focused on citizen journalism activities around Ponorogo and surrounding areas on Gema Surya FM Radio Ponorogo. In this research, the researchers conducted the data collection through: interviews, observation, and documentation.

Data analysis technique is a process of collecting data that is carried out systematically to make it easier to get the conclusion. According to Miles \& Huberman, data analysis is divided into three steps:[4]:

\section{a) Data Reduction}

Data reduction is the process of selecting, simplifying, abstracting and rough data information obtained from notes in the field.

\section{b) Data Display}

In qualitative research, the display of data can be done with various forms of matrices, graphs, networks, tables, and charts, etc.

\section{c) Drawing a Conclusion}

Drawing the conclusions with validity; it is a process in which the meanings emerged from the data during conducting the research must be tested for their truth, robustness, and compatibility.

\section{RESULT AND DISCUSSION}

To explore the data of the research on the Role of Citizen Journalism in Jelajah Pagiprogram on Gema Surya FMRadio Ponorogo, the researchers conducted interviews 
with 2 informants from Gema Surya Radio: Ari Mahendra (Program Director) and Reni Lusiana (Editor). In addition, in order to find out people's opinions about the program, interviews were conducted with 4 people, both listeners and news contributors.

Referring to the types of CJ classified by D. Lasica, here are the analysis of citizen journalism on the PO942 Facebook group [5]:

\section{A. Audiens Participation}

It includes user comments attached to comment on news stories, personal blogs, photos or video images captured from a cellphone camera, or local news written by citizensof a community.

The communication in the forum made by the news team of Jelajah Pagi on Gema Surya radio took place actively, by which all the members actively informed the events they knew in the form of new posts in the group or just simply completed the posted information in the comment column.

Audience participation in the PO942 group was active and the members complemented each other in terms of information or information dissemination. Itwas like the example of a case told by a resource person who mentioned the importance of the active role of the citizen when an accident occured. After the accident, the members who knew the characteristics of the car tried to contact someone who was allegedly the victim's family and it turned out that the person was indeed the victim's family. Everyone involved in it was helped by the information about an event that spread faster and had an impact on the handling of the solution which could also be faster.

\section{B. Independent News and Information Website}

The second type of citizen journalism, according to Lasica, is independent news and information written on the website. Independent news is closely related to the political system and also government in Indonesia. Therefore, a media can be considered independent if it discusses political news or ideas related to the government in a balanced way.

However, over the past 2 years, most of the information in citizen journalism in Jelajah Pagiprogram on Gema Surya $F M$ radio which could be verified on average was news of events such as accidents, natural disasters, etc. since most of the information entered was in the form of events, so it could not be measured independently.

\section{Full-Fledged Participatory News Sites}

Full-Fledged Participatory News Sites are created and published by citizens themselves. According to the researchers, in the 3rd form of citizen journalism according to D. Lasica, citizen journalism on Gema Surya FM was not in the category because the news collection in the PO942 group that dominated was the re-posting of Gema Suryaradio news team even though the initial information was indeed from the citizens. Many citizens were still unfamiliar with this, but the most important thing for now was that the citizens were willing to share information. Citizen journalism in Ponorogo would definitely be better from time to time.

\section{Collaborative and Contributory Media Sites}

Participation in news sites contains reader comments on news that is broadcast by certain media. This includes writing or uploading from the news media through a specific platform that allows citizens to comment by which the active communication takes place. Thus, the communication is not only one-way and is dominated by one source only, but there is an active interaction between the two for the sake of completeness of the information being discussed.

In this study, this happened in the Gema Surya radio facebook group named PO942. Within the group, the citizens actively reported and wrote about events which they found. The uploaded event was certainly information that contained news value. Furthermore, the admin of PO942 also actively uploaded the latest news which was broadcast on Gema Surya FM radio where the original or preliminary information was also obtained from citizen journalism that had been edited and clarified by Gema Surya FM news team. Although the posts were made by the admin, the citizens could still and actively give their comments in the post.

\section{E. Other Kinds of Thin Media}

It includes simple writing like in mailing list and email newsletters. Citizen journalism was an ordinary citizen and most of them did not have special expertise in writing procedures, especially writing news that involved the basic values of journalism. The writing they presented was also very simple and sometimes there was important information missing due to lack of citizens' knowledge, so the information provided was sometimes lacking in detail. It was certainly reasonable and very understandable considering that they really only wanted to share information and they also did not have special abilities in the world of journalism like professional journalists.

Citizen journalism wrote the news simply and with various linguistic styles since basically everyone had different abilities. There were some who wrote neatly and provided complete information, but some of them also provided very simple information. These weaknesses could be minimized by giving opportunities for other members to provide comments to add information so that the information is more complete.

\section{F. Personal Broadcasting Sites}

The 6th type of citizen journalism according to D. Lasica is personal broadcasting sites. According to the researchers, it refers to citizen journalists who have a personal broadcasting sites that is used to share information about events whcih are presented in the form of reporting on their personal broadcasting sites. The personal broadcasting sites can be websites or others that are privately owned and used to be news media.

Gema Surya radio actually already had a personal website, but there was no specific forum for residents to write news. There was only in the PO942 group which was a social media platform and not a personal site. Therefore, based on the analysis of the researchers, this type of citizen journalism did not yet meet the category.

\section{CONCLUSION}

The analysis using D. Lasica's theory regarding types of citizen journalism on the PO942 Facebook group is as follows: 


\section{a) Audiens Participation}

The audience actively participated in the PO942 group and was proven capable of completing information. The citizens already had initiatives to complement information to bring up accuracy in a story.

\section{b) Independent News and InformationWebsite}

In terms of the level of independence, there were several cases of citizens' posts on PO942 that still contained elements of interest from a certain party, but because most of the information was incident information, the level of independence could not be measured yet.

\section{c) Full-Fledged Participatory News Sites}

Full-Fledged Participatory News Sites were created and published by citizens themselves. In the PO942 group, most of the posts were re-posts from the admin of the radio news team, so the news could not be stated purely by citizens since most of the information from citizens was in the form of original or preliminary information.

\section{d) Collaborative and Contributory Media Sites}

Reader comments on news published by the media. The citizens actively commented on the news posted by the admin to the PO942 group, for instance if the team was discussing the news concerned with the daily lives of citizens.

\section{e) Other Kinds of Thin Media}

Other kinds of thin media include simple writings such as in mailing lists and email newsletters. Most citizen posts in the PO942 group were simple, as in the mailing list and email newsletters, due to a lack of citizen knowledge about journalistic basic values.

\section{f) Personal Broadcasting sites}

Gema Surya radio actually already had a personal website, but there was no specific forum for residents to write news. There was only in the PO942 group which was a social media platform and not a personal site. Therefore, based on the analysis of the researchers, this type of citizen journalism did not yet meet the category.

\section{ACKNOWLEDGMENT}

The researchers would like to pay their special regards to Muhammadiyah University of Ponorogo, especially to the Communication Department.

\section{REFERENCES}

[1] A. S. Romli, Bahasa Media: Panduan Praktis Bahasa Jurnalistik. Bandung: Batic Press., 2009.

[2] Nurudin, Perkembangan Teknologi Komunikasi. Jakarta: PT. Raja Grafindo Persada.

[3] Nurudin, Pengantar Komunikasi Massa. Jakarta: PT. Raja Grafindo Persada, 2015.

[4] A. Miles, M., \& Huberman, Analisis Data Kualitatif. Jakarta: Universitas Indonesia Press., 1992.

[5] D. Lasica, Jurnalisme Masa Kini. Peran Jurnalisme Warga Dalam Mengakomodir Aspirasi Masyarakat. 2016. 